\title{
Academic Success: Perceptions of Student-Athletes, Learning Specialists, and Academic Advisors
}

\author{
Lauren Kirby \\ Baylor University \\ Patricia Amason \\ University of Arkansas
}

Abstract: The current study explores how academic success is defined and perceived by studentathletes and athletic academic support staff professionals--learning specialists and academic advisors. One-on-one interviews were conducted with participants from six "Power 5" programs to establish overarching themes. Academic advisors identified academic achievement and personal development as academic success. Learning specialists identified academic success as maximizing individual potential. Student-athletes identified meeting grade-based standards and work ethic resulting in reaching personal goals as academic success; they perceived their advisor identifying eligibility and effort as academic success, and their learning specialist $\mathrm{w}$ view academic success as building academic skills and work ethic. Success among academic advisors, learning specialists, and at-risk student athletes involves attaining academic goals for maintaining eligibility and ultimately graduation, achieving personal development goals of growth, maturity, and increased work ethic. The overarching theme across all three groups identified was effort and was expressed in the form of expectations and considered to be the essence of academic success. As the learning specialist profession continues to grow in college athletics, it is important to understand how learning specialists can collaborate with academic advisors to provide the best overall academic support to student-athletes. The relationship between support staff and student-athletes should result in smoother transitions to college life and assimilation to the demands of athletic participation while meeting academic requirements for eligibility and graduation. Recommendations for learning specialists and advisors are provided in order to improve academic behaviors and build relationships.

Keywords: academic success, student-athlete, learning specialist, academic advisor

\section{Need for Student-Athlete Monitoring}

Low graduation rates in the 1990's and early 2000's led to the discussion of whether colleges and universities provide student-athletes a quality education with the opportunity to graduate or if these students are exploited for their athletic ability. As a result, the National Collegiate Athletic Association (NCAA) created measures for academic reforms that attempted to increase graduation and academic success including Academic Progress Rate (APR), Graduation Success Rate (GSR), and Progress Towards Degree (PTD). Higher level of academic expectations caused institutions across the country to implement a variety of services for student-athletes to assist and monitor their academic progress (Butterworth \& Rich, 2013). While increased academic measures and standards exist, the number of admitted student-athletes is higher who are 
underprepared for college academics, resulting in an even greater need for academic support services (Gurney et al., 2010). Academic support services include academic advisors and learning specialists, tutors, and study hall. At most Division I universities, these services are offered within an academic building designated for student-athlete success (Wolverton, 2016).

NCAA reforms and assessments of academic success target athletic eligibility, progress toward degree completion, and graduation. One issue raised is that these reforms measure "academic progress, not academic performance" (LaForge \& Hodge, 2011, p. 228) and furthermore, such reforms are based on quantity and likely have an impact on quality (Fountain $\&$ Finely, 2011). Some of the foundational studies on academic success argue that success in the classroom does not require using quantitative graded metrics (Tinto, 1997). Currently, an effectively regulated academic progress measure that satisfies all institutions, students, and the NCAA remains missing (Butterworth, 2015).

The increasing focus on retention and academic success resulted in the NCAA and institutions of higher education seeking to identify the variables contributing to desired academic outcomes (Brecht, 2014). A possible issue with only addressing academics is that if support staffs do not know what a student identifies as success, how can they know the best approach and implementation plan for change and growth? To really understand the experience of the studentathlete, support staffs must first look at students' perceptions of academic success in comparison to their own. Once that conversation is established, support staffs can determine the best way to approach students while attempting to help them achieve both their definition of success and push them to their maximum potential.

Overall, research rarely examines how student-athletes define and view their academic success. In addition, few studies have qualitatively studied how athletic academic support staff members communicate and define academic success. The current study investigates studentathletes' perceptions of academic success as well as those of academic support staff in an effort to better understand their academic experience and what they attribute to academic success. The perceptions of academic success and learning outcomes desired by academic advisors, learning specialists, and student-athletes may vary, resulting in a need to better understand these groups and their relationship with one another in order to best serve the student-athletes. The goal of this study is to highlight the views of academic success from non-quantitative standards in hopes of finding ways to celebrate success at every level for every type of student.

\section{Academic Success}

Academic success in college is either seen as cognitive (intellectual), non-cognitive (attitudinal or motivational), or both. Past studies focus more on cognitive variables than the noncognitive ones that contribute to academic success (Hyatt, 2003). The most common cognitive variables used are standardized test scores (ACT/SAT), GPA, course grades, and graduation rates. However, researchers (Russell \& Petrie, 1992; Sedlacek, 1987; Tracey \& Sedlacek, 1985) state that for some populations, nonacademic variables are better predictors of academic success. Ting (2009) discovered that both non-cognitive and cognitive variables are better predictors of academic success for student-athletes. 
Different definitions currently exist in studies that examine academic success for both student-athletes and entire college student populations. In studies investigating student-athlete academics, GPA often serves as the standard measure of academic success. Various student accomplishments also are used to measure student success. Academic success is a value-laden term indicating that students have fulfilled their intended educational goals or aspirations (Floyd, 1988). It can be defined as the extent that intended goals are achieved (Braxton, 2003) and can be applied to varying degrees of student accomplishment during their academic tenure (Horton, 2009). At the institutional level, success occurs when staff members focus less on the skills students bring to college and focus more on their intentional skill development when they leave (Roueche \& Baker, 1987). Other studies use academic success and persistence together (Gragg \& Flowers, 2014) and proficiency and understanding of subject matter developed to the point that a student could advance to the next course level in the same content area (Conley, 2007). A more introspective version of academic success targets a person's self-perception of their own academic and intellectual development (Rankin et al., 2011).

For the NCAA, academic success is measured according to athletic eligibility, progress toward degree completion, and graduation (Cooper et al., 2017). Dilley-Knoles et al. (2010) found that while the NCAA has established programs assisting in student-athlete success, the formula for success is a holistic concept requiring uniquely different approaches based on the individual. The "one size fits all" may not be an effective method for helping student-athletes academically. How success is defined and perceived can have adverse effects on student-athletes. The differences in how students feel about academics compared to academic performance should raise concern about what constitutes academic success and to whom (Cooper et al., 2017). What is missing from the current literature are the views student-athletes have of success and what experiences led to their feelings of success. Identifying the characteristics of success from the voices of student-athletes is one goal of the current study.

\section{Academic Support Programs}

Currently, the NCAA places the responsibility for quality educational experience on each institution (Hanna, 2013). In 1991, the NCAA mandated that Division I universities provide academic counseling and tutoring services to all student-athletes (NCAA Division I Manual, 2012). Support programs offered vary by school, but the NCAA lists services that should be provided: "Academic counseling/advising resources and services, tutoring, academic progress monitoring and reporting, assistance for student-athletes with special academic needs, assistance for student-athletes, academic support facilities, academic evaluation of prospective studentathletes, and student-athlete degree selection" (NCAA Academic Support Services Evaluation Guide, 2009).

Gurney et al. (2010) championed the athletic academic support unit involving stakeholders as vital to student-athlete success. However, existing literature is inconclusive about what academic support services increase student-athlete success (Autry, 2010). Some programs spend more than three million dollars a year on academic support for student-athletes, with much of this budget used to help students with more serious academic challenges (Wolverton, 2016). As a result, $86 \%$ of NCAA institutions have academic programs specifically for student-athletes (Stokowski et al., 2014). Despite the responsibility of academic support units to effectively meet the needs of all student-athletes, little is known about effective academic programs and how they 
influence student-athletes' perceptions of their academic success. In the following sections, distinctions are made between the roles of academic advisors and learning specialists.

\section{Academic Advisors}

When Proposition 48 was introduced in 1983, the role of academic advisors for athletics covered "eligibility monitoring, course selection, act as an intermediary between athletes and faculty, assessment of skills deficiencies, provide tutoring, provide study halls, help with major selection, personal counseling (including role conflict and self-concept) and career counseling" (Figler, 1987, p. 77). In 2013, the National Association of Academic and Student-Athlete Development Professionals, also known as N4A, updated the advisor role to include: (a) ongoing collaboration with campus units to educate student-athletes on academic opportunities, major and course options; (b) review by semester student-athlete course enrollment compared to overall campus student enrollment; (c) annual review of distribution of student-athletes across majors on campus; (d) document procedures for student-athletes academic advising; (e) ongoing education of academic support staff in campus academic programs; (f) facilitating communication between academic support personnel and campus advisors; (g) regularly connecting student-athletes with major and college advisors; (h) outreaching efforts with campus career services and student-athlete development offices connecting major selection with career objectives and job placement; and (i) involving student-athletes in all academic advising conversations. Advisors should also be knowledgeable about the unique stressors that student-athletes face. Additionally, advisors are to monitor the academic progress of assigned student-athletes in accordance with the NCAA, conference, and university requirements (Hanna, 2013).

The primary goal of an academic advisor is to help student-athletes achieve educational goals, timely graduation, and preparation for lifelong learning and meaningful employment (Hanna, 2013). However, the role of the academic advisor for athletics evolved to focus more on initial and continuing eligibility (Grandy et al., 2016) and academic advisors have been accused of acting as "eligibility brokers" whose main goal is to keep student-athletes eligible to play their sport (Meyer, 2005). Research shows that some student-athletes are unsuccessful in college when advised based on maintaining athletic eligibility instead of primarily for their personal development and academic interest (Hittle, 2012). Research reveals that advisors are supportive of student-athletes (Butterworth \& Rich, 2013). However, they are often charged with disabling students from making their own decisions and even from developing the decision-making skills necessary for college success (Hardin \& Pate, 2013).

\section{Learning Specialists}

The implementation of more rigorous academic standards by the NCAA in the 1990s created the need to establish the learning specialist role. The broadened definition of disability and more inclusive criteria for accommodations led to more student-athletes with learning disabilities meeting NCAA regulations, which increased the need for learning specialists into the early 2000s (Goforth, 2016).

The number of students admitted to higher education institutions who have learning disabilities or cognitive challenges increased considerably_ “doubling or tripling" in recent years-causing the learning specialist to have a more permanent and active role in athletic 
academic support units (Wolverton, 2016, p. A14). According to the 2017-2018 learning specialist and tutor coordinator census data, Power 5 conference institutions may have multiple learning specialists on staff, Group of 5 conference institutions may have one, and mid-major conference institutions may have a learning specialist hybrid position or none at all (Steinberg et al., 2018). Learning specialists work with student-athletes who are diagnosed with learning disabilities or who are academically underprepared and struggling to transition to college rigor. A survey (N4A, 2007) found that learning specialists come from many different professional backgrounds, including counseling, education, and special education, and their top four responsibilities are teaching learning strategies, time management skills, organizational skills, and working with student-athletes with learning disabilities. There was a high level of variance between services offered between universities, but as reported by Steinberg et al. (2018), the demand for learning specialists is growing at a significant rate. For student-athletes who have a diagnosed learning disability, learning specialists are liaisons to disability services on campus and help students to make appointments and understand their accommodations. Additionally, if a student-athlete is suspected of having a disability, a learning specialist may recommend that a full psychoeducational evaluation be conducted.

For each student, learning specialists develop and implement individualized support plans based on the student's specific strengths and weaknesses. They also address skills such as selfdetermination, self-management, and technology, all of which are labeled as critical to studentathlete college success (Getzel, 2008). A case study by Weiss (2011) cited that the goal of a learning specialist was to provide initial transitional support to student-athletes and for them to work towards becoming independent from their services by the end of their second academic year. A recent study determined that the roles of learning specialists are to work individually with student athletes, regardless of their academic preparedness, to develop the most effective learning strategies and to remind the students about their schedules and obligations (Steinberg et al., 2018).

Lightfoot (2014) discusses the complex role of the learning specialist and claims that a learning specialist is the "objective person in the middle ground trying to decipher and balance the academic aptitude, course-load and classroom maturity and development by the student-athletes under their purview" (p. 35). In addition, he also emphasized the caring and compassionate role that a learning specialist takes: "this singular person is the one I believe mitigates my studentathletes stress by being an honest, compassionate leader . . o operates with a firm hand" (p. 35) with a high degree of loyalty to the position. There is a gap in the literature about the complexity of the role learning specialist play that needs further investigation. If the "hottest hire in athletics" is a learning specialist (Wolverton, 2016), there is a need for more research on what exactly that hire entails and how it works in conjunction with the rest of athletic academic support staff. Thus, the purpose of the current study is to examine how learning specialists, academic advisors, and student-athletes view academic success. The following four research questions are raised:

RQ1: How do academic advisors working with student-athletes define academic success? RQ2: How do learning specialists working with student-athletes define academic success?

RQ3: How do student-athletes define academic success?

RQ4: What do student-athletes perceive their academic advisors and learning specialists identify as academic success for them? 


\section{Methodology}

The current study was exploratory because little research examines the relationships/interactions among learning specialists, academic advisors, and student-athletes. The voices of persons who play those three roles provide the richest types of data for gaining a better understanding of how academic advisors and learning specialists instill student-athletes' positive attitudes towards academic success. The need for more qualitative research looking at student success is highlighted in extant research (Van Etten et al., 2008). The lack of literature reflecting voices of students' academic success was sought to "understand the phenomenon of academic success by listening to the words of the students themselves" (Fauria \& Zellner, 2015, p. 92).

Qualitative research is an inductive method starting with the data and the theories derived from that data (Orcher, 2016). Therefore, using qualitative methods is appropriate when researching a new phenomenon, since previous data or existing theories are scarce upon which to draw. A qualitative approach also proves helpful when studying the knowledge and practices in a particular field from a variety of participants' perspectives and backgrounds. Following a grounded theory approach, the present research focused on the voices of the student-athletes, learning specialists, and academic advisors rather than their comments on preformulated surveys. Researchers of grounded theory seek the ideas of others, how they view the situation of interest, gather their personal experiences, allow participants to offer details of those experiences, and share their accounts of those experiences through storytelling (Glaser \& Strauss, 1967).

\section{Sample}

Mason (2002) emphasized the importance of sampling and participant election in qualitative research projects. For this reason, 18 participants for this study were selected using purposeful sampling and purposeful recruitment, respectively (six athletes, six learning specialists, and six advisors). Though this relatively small sample may not be as informative as a larger sample, this study is exploratory in nature and these participants are "information rich" (Hennink et al., 2011; Patton 2002) and they are evenly matched among the roles of academic advisor, learning specialist, and academically at-risk student athlete. These are students who marginally met admission standards of their respective colleges and universities due to low high school GPA and/or low scores on ACT or SAT college admission exams. Moreover, saturation of the data was reached during interviews with these persons.

Criterion sampling was used to identify participants. First, they were to represent the Power 5 conferences. The contact information of either academic advisors or learning specialists from each school in these conferences was obtained, and they identified the student-athletes. Second, the student-athlete needed to have regular meetings with both a learning specialist and an advisor, with preference given to juniors or seniors academically. These guidelines were used to ensure the students could speak about their relationships over time with their academic advisor and learning specialist about their academic pursuits. Fifteen of the interviews were held over the telephone and three were conducted face-to-face and audio recorded, resulting in six with learning specialists, six with advisors, and six with student-athletes who were from six different academic institutions representing four of the Power 5 conferences (SEC, ACC, PAC 12, and Big XII conferences). 
Demographic information was obtained in the initial portion of interviews through verbal self-identification and was collected in order to describe the sample. The learning specialists and advisors were asked their race, sex, age, level of education obtained thus far, and how long they had worked in academic support services. Eight of the professionals were female and two were male. All of the student-athletes were male.

Participant recruitment. Participants were recruited once approval from the university's Institutional Review Board (IRB) was obtained. Letters soliciting requests for participants from each of these populations were sent to the director of student-athlete academic support at every institution in the Power Five FBS (Football Bowl Subdivision) conferences. The letter requested permission to conduct a semi-structured one-on-one interview with a learning specialist, an academic advisor, and a student-athlete at their institution. In addition, the IRB protocol approval form, participant consent forms, and the list of interview questions that would be used were included in the letters. Overall, 18 individuals at six different FBS institutions from varying conferences and regions participated and represented a broad range of experiences.

\section{Procedures}

Informed consent forms were issued to each interviewee guaranteeing the anonymity of any answers or identifying information released by the participants. Per IRB request, the studentathletes were asked to sign a consent form at the beginning of their interview. To uphold confidentiality, participants were referred to as "one learning specialist/advisor/student stated...." or "one participant stated" in order to ensure anonymity. Interview questions were developed specifically for the study and interviewees were invited to provide as detailed of an answer as they saw fit. If the opportunity allowed or was necessary, responses were probed to allow for greater detail. The interviews ranged from 14-45 minutes for academic advisors, 24-61 minutes for learning specialists, and 8-29 minutes for student-athletes. Participants were informed that they could remove themselves from the study at any time.

\section{Pilot Testing}

Pilot testing evaluated and determined the effectiveness of the interview questions. Individuals participating in the pilot study were recruited using personal contacts from each of the three populations. Pilot participants helped with modifying interview questions to make them clearer and more applicable. The only changes made included adjusting wording to help clarify the main intent of the question and adding a few ideas for probing questions.

\section{Data Analysis}

Content analysis is a method that enables the researcher to make legitimate inferences about the content and context of messages through the process of analyzing data for reoccurring themes (Baxter, 1991). Thematic analysis, a form of content analysis, uncovers common themes among narrative accounts (Krippendorff, 1980). Thematic content analysis was used to identify emerging themes within the data along with the grounded theory approach (Glaser \& Strauss, 1967) to create overarching themes addressing the four research questions. 
After completing the interviews, the audio recordings were transcribed verbatim, including incorrect grammar and mispronounced words. Thematic analysis generates common themes about relational discourse using a triangulation approach consisting of specific criteria. The data were analyzed according to the three specific criteria of recurrence, repetition, and forcefulness. Recurrence occurs when a theme is expressed multiple times throughout discourse. Different words can be used to describe the phenomena, as long as the language denotes similar meaning. Repetition indicates that a theme is conveyed through use of exact discourse. In addition, forcefulness, including "vocal inflection, volume, or dramatic pauses serving to stress and subordinate some utterances from other locations in oral reports" and can indicate a theme present in the data (Owen, 1984, p.275).

The grounded theory approach was used to answer the research questions through open coding, axial coding, and developing core categories (Orcher, 2016). In the process of coding the data, communicative codes and themes were found relating to the research questions. After compiling codes and creating themes and subthemes for each participant group, overarching themes were revealed in the data.

The data were analyzed separately according to the three roles. First, each transcript was read for comprehension and to refresh what occurred during the interviews. Each transcript was re-read at least two more times or until the overall meaning was understood and analytical notations were made as reminders for subsequent coding (Saldana, 2016). Next, each transcript was read again for common occurrences across the data with colored markers. Additionally, key phrases, explanations, examples, and ideas expressed by each participant were noted. This process was repeated by the first author multiple times to make sure all of the key components were noted.

This process resulted in narrowed down text and an overall sense of meaning with the grounded theory approach of open coding used. The compilation of keynotes taken from each participant's transcript was read allowing for "coding" for separate ideas identified through the reoccurring, repetitive, or forceful thoughts and language previously identified. A list of bolded codes for each interview question along with subcategories was noted. For example, the code "growth" might have two sub codes: academic and personal. The transcripts were read again to make sure the codes identified were accurately portrayed.

The final stage of the grounded theory approach involves developing core categories through axial coding. To derive common units of meaning across participants, similar ideas/codes were sought that emerged repeatedly throughout each transcript. A table for the research questions was created illustrating the overarching themes and reoccurring major themes found for each population based on the codes and categories collected from the interview questions. The final stage of the grounded theory approach involves developing the core categories. To derive common units of meaning across participants, similar ideas/codes were identified that emerged repeatedly throughout all transcripts. The codes then were examined for overarching themes and subthemes. These overarching themes attempt to describe the process and relationship of how the themes and subthemes work together (Orcher, 2016). To develop into a theme or subtheme, the code had to appear in the data at least two times by two different participants. Finally, all of the relevant data were organized according to how they answered each of the four research questions. After completing separate analyses of the groups, similarities and differences were noted in the themes between and across the participant groups. 


\section{Results}

Table 1

Research Question 1: How Do Academic Advisors Define Students'Academic Success?

\begin{tabular}{|c|c|c|}
\hline & Overarching Themes & Major Themes/Examples from the Data \\
\hline Population & & \\
\hline $\begin{array}{l}\text { RQ 1: Academic } \\
\text { Advisor }\end{array}$ & $\begin{array}{l}\text { Personal Development } \\
\text { Academic Achievement } \\
\text { 2a. Degree Completion }\end{array}$ & $\begin{array}{l}\text { Growth/Development } \\
\text { I also think for some students experiencing } \\
\text { new things and being active can be success. } \\
\text { Growing as a person, maturing...I think } \\
\text { students obviously mature, they come in young } \\
\text { and naïve and wide-eyed and silly, and they } \\
\text { kind of grow up a little bit. } \\
\text { "How do they become independent learners } \\
\text { and how are they able to utilize support, but } \\
\text { grow through that person in order to become } \\
\text { able to do work in their own ...it is a process." } \\
\text { I think always when we look at (academic } \\
\text { success) we look at maximizing ability and } \\
\text { potential for each student. I think that being } \\
\text { said, graduation is always the ultimate goal } \\
\text { for all of our students that we have that come } \\
\text { through our program, so that is the main one. } \\
\text { I think that graduation is definitely probably } \\
\text { number one or key priority...They are coming } \\
\text { to school maybe to do other things, but they } \\
\text { are coming to school to get their degree and } \\
\text { work towards that degree. I think that is the } \\
\text { ultimate level of academic success. } \\
\text { "walk away having some value and just } \\
\text { different life experience-figuring out what life } \\
\text { is about." } \\
\text { "Academic success is based on the ability of } \\
\text { the student-athlete you are working with and } \\
\text { is that student meeting the standard that their } \\
\text { ability provides...Some students are far less } \\
\text { prepared for college and the rigor of college. } \\
\text { Academic success for them is garnering the } \\
\text { skill set to become independent. So it is }\end{array}$ \\
\hline
\end{tabular}




\begin{tabular}{|c|c|c|}
\hline & 2b. Individual Standards & $\begin{array}{l}\text { definitely dependent because it is always about } \\
\text { meeting the individual standards for that } \\
\text { student." } \\
\text { "To me, that is successful if they can achieve } \\
\text { what their baseline is and if I can push them a } \\
\text { little bit further." }\end{array}$ \\
\hline $\begin{array}{l}\text { RQ 2: Learning } \\
\text { Specialist }\end{array}$ & $\begin{array}{l}\text { Maximizing Individual Potential } \\
\text { Personal Best } \\
\text { Self-Awareness and Skill } \\
\text { Development }\end{array}$ & $\begin{array}{l}\text { Reaching Individual Academic Potential: } \\
\text { "I think for some people those standards are } \\
\text { higher and for some lower. I think as long as } \\
\text { they are doing the best they can, and figuring } \\
\text { out how to be successful then I would call that } \\
\text { success." } \\
\text { "being able to understand your strengths and } \\
\text { weaknesses." } \\
\text { “...having a sense of competence and knowing } \\
\text { where to go to get help or being able to ask for } \\
\text { help when you know that you need it or being } \\
\text { able to handle things on your own and being } \\
\text { aware of your own stuff. Your own learning } \\
\text { style, your own learning approach, being } \\
\text { aware of how you learn best for whatever } \\
\text { topic." } \\
\text { "they couldn't put three sentences on a piece } \\
\text { of paper when you first started but by the time } \\
\text { they graduate they are over there just typing } \\
\text { away on a paper and only ask you a few } \\
\text { questions." } \\
\text { "being able to analyze, evaluate, and create } \\
\text { which would be the hierarchy of Bloom's } \\
\text { taxonomy. To me, that would be academic } \\
\text { success, being able to achieve that level of } \\
\text { thinking in multiple disciplines." } \\
\text { "didn't care... and they come back and (they } \\
\text { are) proud of the C." Or when a student } \\
\text { being here, and then eventually the goal of } \\
\text { success is getting them to be independent." }\end{array}$ \\
\hline
\end{tabular}




\begin{tabular}{|c|c|c|}
\hline & Engaging in the Process & $\begin{array}{l}\text { Autonomy/Independence } \\
\text { "I want them to embrace that and appreciate } \\
\text { that and to do the best that they can do within } \\
\text { their own based on who they are." }\end{array}$ \\
\hline $\begin{array}{l}\text { RQ 3: Student- } \\
\text { Athlete }\end{array}$ & $\begin{array}{l}\text { Meeting Grade Based Standards } \\
\text { Goals } \\
\text { Work Ethic Resulting in Personal } \\
\text { Goal }\end{array}$ & $\begin{array}{l}\text { Achieving what I know I am capable of: } \\
\text { "To me, I know what I am capable of and when } \\
\text { I feel like I am living up to the standard that I } \\
\text { set for myself." } \\
\text { "finish above a } 3.0 \text { overall when I graduate. } \\
\text { Get a degree." } \\
\text { "The grade I get, I would want to be an A or B, } \\
\text { but if I knew I tried and I still got around a 70, I } \\
\text { would be fine with it." } \\
\text { Passing/good grades: } \\
\text { "Having a good core GPA, having a good GPA } \\
\text { at the end of the semester, passing all of my } \\
\text { classes..." or "... good grades, I feel like that is } \\
\text { success. Just not failing any classes, that is a } \\
\text { huge success for me too." } \\
\text { "Stay on top of your stuff, your assignments, } \\
\text { your grades. Keep your GPA up...Do all your } \\
\text { assignments on time so that at the end if you do } \\
\text { bad, your grade won't drop bad because you } \\
\text { were always doing the assignments and you } \\
\text { were always on track." } \\
\text { Work Ethic: } \\
\text { "Academic success is basically getting } \\
\text { everything of school right now...I want to finish } \\
\text { it how I know I can. Like I don't wanna just } \\
\text { pass, I want to be the best that I can... That is } \\
\text { academic success to me, just really putting an } \\
\text { effort towards everything I am doing now." } \\
\text { "... learning how to do the work that needs to } \\
\text { be put in for the workplace and regular life } \\
\text { after college." }\end{array}$ \\
\hline
\end{tabular}




\section{Research Question 1: How Do Academic Advisors Define Students' Academic Success?}

Personal Development and Academic Achievement in the form of degree completion and student-athletes' individual standards were the most prevalent responses. Coded as Personal Development, many advisors expressed the importance of students growing as a person during their time at an institution. While degree completion was identified as the overall goal, some advisors offered the ability to do what it takes to get a degree as a sign of success. The most identified theme was graduation/completion of the degree. In every interview except one, graduation or degree completion was coded as Academic Achievement. Although other factors pertaining to success were identified, it was communicated that the ultimate goal was degree completion/graduation based on its frequency in the data.

An advisor expressed that the ultimate level of success is graduation since student-athletes are working towards a degree while they are enrolled. One advisor expressed the importance and lasting value of a degree for setting up student-athletes for success once they leave campus. Advisors also acknowledged that students enter college with different levels of academic skills and preparation. Since these differences can influence academic achievement, success is evident when their academic skills allow them to progress through their major, ultimately encouraging the student-athlete to push further.

\section{Research Question 2: How Do Learning Specialists Define Students' Academic Success? (see Table 1)}

The overarching theme was Maximizing Individual Potential. The data revealed a type of academic success involving pushing limits to achieve the student-athlete's personal best. Thus, success comes from skill development, a sense of self-awareness, and a level of engagement leading to autonomy. These findings are described below.

\section{Personal Best}

Participants expressed the importance of evaluating success based on the individual's own ability. One learning specialist identified academic success as student-athletes performing to the best of their abilities, especially when they exceed those standards that are expected of them.

\section{Self-Awareness and Skill Development}

Learning specialists expressed academic success as a student's ability to be self-aware as a learner and develop the skills to help them academically that they did not have before college. Another stated that success is about leading student-athletes in learning to understand their strengths and weaknesses. Success also involves "figuring out how to be successful." Selfawareness was described as having competence in knowing who to go to for assistance and understanding how the student-athletes learn and what strategies are the most effective for them to use in achieving academic success. One learning specialist gave an example of what skill development might look like as occurring when a student-athlete lacks basic writing skills upon entering college and working to eventually demonstrate the ability to successfully write a term paper. In a more general sense, one learning specialist expressed that grades do not define 
academic success. Instead, if a student leaves the institution with a more advanced level of thinking, he is successful.

\section{Engaging in the Process}

The last theme for academic success offered by learning specialists dealt with effort and navigating college. One participant expressed that success occurs if a student who struggled to pass in high school due to lack of academic skills develops a positive attitude about school. Embracing and appreciating the value of their opportunity and where it can take them was found to indicate success, as well. Along with caring about and buying into the system, learning specialists also expressed adjusting to college as success. They also described this life transition as difficult for student-athletes lacking the academic preparation for the rigor of college classes. Success would be evident when they demonstrate an understanding of how the system works and maintain an acceptable academic record.

\section{Research Question 3: How Do Student-Athletes Define Academic Success? (see Table 1)}

\section{Meeting Grade Based Standards}

Student-athletes indicated maintaining an acceptable GPA as the main indicator of academic success. Some expressed having a specific GPA as an academic goal for completing their degree. Others were more vague and only indicated GPA in its relationship to passing or even merely not failing. Some expressed the importance of staying on track and completing assignments, but again, it came back to GPA. One offered the importance of their being able to stay up-to-date on assignments and not fall behind as being successful.

\section{Work Ethic Resulting in Personal Goals}

The additional theme that emerged regarding research question three went beyond grades and dealt with work ethic and personal goals. One student-athlete expressed that passing does not indicate success. To him, success is performing academically to his highest capacity and putting in the work to achieve that standard. Success is not just making a passing grade, but doing his very best. Another student-athlete expressed that success is built on his own standards and expectations, knowing what his capabilities are, and living up to those standards. Another student-athlete noted that while "passing with a good grade" was the goal, he would be satisfied knowing he put effort in and worked hard for the grade he earned. It also was mentioned that success could deal with establishing a work ethic that will transition to life after college. 


\section{Table 2}

RQ 4: What Do You Think Your Academic Advisor and Your Learning Specialist Would Identify as Academic Success for You?

\begin{tabular}{|c|c|c|}
\hline Population & Major Theme & Sub Theme/Examples from the Data \\
\hline $\begin{array}{l}\text { Student- } \\
\text { Athlete/Academic } \\
\text { Advisor }\end{array}$ & . & $\begin{array}{l}\text { GPA } \\
\text { "Getting all } 12 \text { hours so that you are eligible to } \\
\text { play. So that is the goal no matter what. You } \\
\text { have a low GPA, but as long as you are eligible, } \\
\text { I feel like is the ultimate goal as far as } \\
\text { academics go. And they are the one that has to } \\
\text { tell the coaches he can't play this season } \\
\text { because you aren't eligible." } \\
\text { "Well C's are definitely not in the picture. I } \\
\text { don't even remember the last time I get C's } \\
\text { unless it is a really tough class or if I knew I } \\
\text { would get a C...Sometimes you think that } \\
\text { another class is more important, but if bring } \\
\text { back C's everybody is like that is unacceptable } \\
\text { because they know I can do better. Every } \\
\text { semester for the past } 4 \text { semesters I have had a } \\
3.3 \text { or higher so I have a high standard and they } \\
\text { expect me to be that role model for the rest of my } \\
\text { teammates and show the younger people that } \\
\text { this is what you need to be at and let's not settle. } \\
\text { That is the minimal; C's is the minimum. And } \\
\text { some classes and courses or harder than others } \\
\text { and certain majors but you set the example like } \\
\text { you can do it and that if you just put the work in } \\
\text { you get great results." } \\
\text { Degree/Graduation } \\
\text { "Graduating on time." Another stated, } \\
\text { "Getting a degree." } \\
\text { "coming in and everything, being in class all } \\
\text { the time...”" }\end{array}$ \\
\hline
\end{tabular}




\section{Table 3}

RQ 4: What Do You Think Your Academic Advisor and Your Learning Specialist Would Identify as Academic Success for You?

\begin{tabular}{|c|c|c|}
\hline Population & Major Theme & Sub Theme \\
\hline $\begin{array}{l}\text { Student-Athlete/Learning } \\
\text { Specialists }\end{array}$ & Work Ethic & $\begin{array}{l}\text { Effort is more important than the grade } \\
\text { "They want you to get good grades, but they } \\
\text { really want you to put the time in your work. } \\
\text { Like if you get a C and put all your work ethic is } \\
\text { good. Like you get work done and you get a C } \\
\text { then so be it because you worked hard on it and } \\
\text { you finished it. But you have to do everything } \\
\text { possible for you to get a good grade. I used to } \\
\text { turn my papers in four or five days early to get it } \\
\text { viewed by the teacher and then they will send it } \\
\text { back and I fix whatever, if I still got a C but I did } \\
\text { everything possible to get an A or a B but if I } \\
\text { still got a C then as long as I put the effort in. } \\
\text { You gotta know what you are putting in. I think } \\
\text { academic success to them is just doing } \\
\text { everything you can possible to get the best grade } \\
\text { possible." } \\
\text { "Just learning how to put in the effort that is } \\
\text { going to make you successful in whatever job } \\
\text { you do. She doesn't really care about what } \\
\text { grades I get as long as I put in the work and do } \\
\text { the best that I can." } \\
\text { "Like when I first came in I didn't like doing } \\
\text { papers as much. My papers were kind of bad, } \\
\text { like grammar and stuff. I used to just write and } \\
\text { didn't make any grammar corrections. And now, } \\
\text { she will read my papers and say I am a better } \\
\text { writer." } \\
\text { "Pretty much the small things. The small } \\
\text { achievement that you may have like doing good } \\
\text { on a discussion board." }\end{array}$ \\
\hline
\end{tabular}

\section{RQ 4: What Do You Think Your Academic Advisor and Your Learning Specialist Would Identify as Academic Success for You?}

Eligibility

Advisors' and learning specialists' views of success, from the student-athletes' perspective, included components of eligibility (i.e., meeting the minimum requirements to play set by the NCAA). Two student-athletes stated that their advisors and learning specialists encouraged their being eligible to play much like their being prepared to graduate on time. One explicitly claimed he thought his advisor viewed his maintaining eligibility as academic success. Specific grades were also identified: "A's and B's." One student believed that the standard for 
success was set by his past academic performance and that being labeled as a team role model reinforced this academic expectation.

\section{Effort}

Effort (e.g., showing up to appointments and going to class) was also cited as studentathletes' views of his advisor's and learning specialist's definition of success. Student-athletes perceived that learning specialists would say that work ethic is more important than the grade and academic success is how they build academic skills. For example, one student identified the academic behaviors of being in class, study hall, and tutoring appointments on time as being successful in their advisor's eyes. Student-athletes indicated that work ethic is more important to a learning specialist than the student's grades. Additionally, student-athletes offered that learning how to work hard to set themselves up for success in the working world was also seen as their learning specialists' views of success. Student-athletes also expressed that their advisors and learning specialists encourage their success by helping them to set goals and work hard to accomplish even the small improvements.

\section{Discussion}

The argument of whether a student-athlete is successful or unsuccessful is based on a preconceived, predefined measure of academic success. The NCAA and most research equate academic success with GPA, GSR/Federal Graduation Rate (FGR), and APR. The problem with this is that academic success has a variety of meanings for different people in varied contexts. In the literature, various student accomplishments are used to measure student success. Academic success is a value-laden term indicating that students completed their intended educational goals or aspirations (Braxton, 2003; Floyd, 1988) and can be applied to varying degrees of accomplishment experienced by students during their academic tenure (Horton, 2009). At the institutional level, success occurs when staff members are less focused on the skills students bring to college and more focused on intentionally developing the skills students have acquired by the time they leave (Roueche \& Baker, 1987). There is a lack of research examining how advisors, learning specialists, and student-athletes define and view academic success. The current study sought to fill this void.

Researchers have examined variables of academic success with hopes of finding the answer to make sure student-athletes are successful. They also focused on identifying which types of variables most significantly affect academic success in order to reinforce the behaviors leading to student-athlete academic success. The problem is that in order to change a behavior, you first need to know what behaviors most likely lead to success. If support staff members do not know what a student identifies as success, how can they know how to best approach and implement a plan for change and growth? In order to really understand the experience of the student-athlete, support staff members first must look at students' perceptions of academic success in comparison to their own. Once that is established, support staff members can determine the best way to approach students in an attempt to help them achieve their definition of success and then push them to their maximum potential. These efforts involve helping student-athletes identify the most engaging academic majors for them, then selecting whatever forms of assistance will most likely lead the student-athletes to achieve academic goals, and changing academic behaviors that ultimately lead 
to graduation. This finding is consistent with the views of Nichols et al. (2019), who describe differences between high and low academic performers. Nichols et al. differentiate these performers who are student-athletes as having a mindset to grow as individuals and to improve their academic and athletic skillsets. Additionally, Nichols et al. indicate that high academic performers had a significantly larger number of academic experiences such as computer use, using the library, or asking for feedback on assignments from a professor or a friend than did low academic performers.

There is a gap in the qualitative research exploring both what it takes to facilitate academic success for student-athletes when they enter college, as well as how student-athletes experience their schooling and the programs and interventions put in place to help them succeed academically (Benson, 2000). This study explored six Division I student-athletes' perceptions of academic success, as well as the perceptions of the academic support given to them by learning specialists and advisors. The purpose of this investigation is to better understand their academic experiences and give administrators information to make data-based decisions on how an institution can best support their student-athletes.

The first three research questions sought to determine how academic success is perceived from the perspectives of academic advisors, learning specialists, and student-athletes. Academic advisors identified academic achievement in the form of degree completion and individual standards, and personal development as academic success. Learning specialists identified academic success as maximizing individual potential through personal best, self-awareness, skill development, and engaging in the process. Student-athletes identified meeting grade-based standards and having a work ethic resulting in reaching personal goals as academic success for themselves. Student-athletes perceived that their advisor would identify: eligibility (e.g., graduation/degree and GPA) and effort (e.g., showing up to appointments and going to class) as academic success, and that their learning specialists would say that work ethic was more important than the grade and academic success was equated to building academic skills.

Advisors indicated that academic success is personal development and academic achievement in the form of degree completion and individual standards. As the results showed, advisors did not see graduation as the only measure of success. However, every advisor except for one mentioned success as being "the ultimate" form of academic success and graduation. This makes sense since the NCAA created the advisor position in an attempt to increase graduation rates of student-athletes (Hanna, 2013). The main features in their job description deal with facilitating progression towards graduation, and more broadly, eligibility. It may be that advisors define academic success for students in a way that coincides with their primary responsibilities as an advisor, and in turn, influence their communicative styles and relationships with studentathletes.

Learning Specialists emphasized that successful student-athletes are able to set a standard for themselves and work hard to attain their academic personal best. Additionally, these professionals see success when student-athletes show their self-awareness and their demonstration of high-level academic skills. These findings support those of Horton (2009). He found that student-athletes defined success as finding personal happiness, passing all of their classes, being productive in the classroom, meeting academic requirements to maintain athletic eligibility each semester, and having a good athletic season both individually and collectively. Similarly, this study 
found that student-athletes identified meeting grade-based standards and having work ethic resulting in reaching personal goals as academic success for themselves.

In his study, Heinel (2008) found that student-athletes thought successful academic behavior included sitting and listening to teachers and then finding someone who would either assist them with their assignments or complete their assignments for them. While no students in this study identified anyone else doing their work, they did indicate that learning specialists helped them get organized and stay on track when completing their assignments. Assignment completion was a major component in the perception of academic success.

Student-athletes identified effort and components of eligibility (e.g., graduation, degree progress, and GPA) as what their advisor would identify as success for them. It is interesting that factors of eligibility were identified with what student-athletes thought their advisor would identify as academic success, since that is the primary focus of the advisor's role. Student-athletes indicated not just graduating but "graduating on time," and not just passing classes but "getting all 12 hours so you are eligible to play" as signs of success to their advisors. Behaviors that affect eligibility were also communicated as being part of success, including "being in class all the time." Studentathletes are normally class-checked to ensure attendance accountability between advisors and coaches when students miss class. How student-athletes answered what they believed their advisors would identify as academic success for them may be influenced by the communication style of their advisors. This impacts how advisors deal with coaches, institutional standards, and NCAA eligibility requirements.

Student-athletes said that their learning specialists thought that work ethic is more important than a grade and that academic success is based on their building academic skills. They also indicated that growth and small successes ultimately were seen as successful to their learning specialist. The idea of working hard, even if the grade earned is not as high as expected, reflects that learning specialists and student-athletes worked together towards growth in the academic process, which can take time. Overall, there was accuracy among what student-athletes believed their advisors and learning specialists would identify as academic success for them and what learning specialists and advisors, themselves, described as academic success.

Effort was an overarching theme of every participant group in this study, as expressed in the forms of expectations and considered academic success. The findings indicate that students increased their effort and their standards/goals for themselves when they experienced a small taste of academic success and saw that they were capable. For example, one student-athlete offered,

Well C's are definitely not in the picture. I don't even remember the last time I get C's unless it is a really tough class or if I knew I would get a C...Sometimes you think that another class is more important, but if bring back C's everybody is like that is unacceptable because they know I can do better. Every semester for the past 4 semesters I have had a 3.3 or higher so I have a high standard and they expect me to be that role model for the rest of my teammates and show the younger people that this is what you need to be at and let's not settle. That is the minimal; C's is the minimum. And some classes and courses or harder than others and certain majors but you set the example like you can do it and that if you just put the work in you get great results. 
Clearly, this particular student-athlete set higher goals for himself than what making a $\mathrm{C}$ in a class represents for most of his classes; he couldn't remember making a grade that low. His only justification for working hard and still earning a $\mathrm{C}$ was if the class was especially hard. He admits that he is working with higher standards than in the past. He also felt that his teammates looked up to him as an example what should be expected from succeeding in the student role of a studentathlete. He stresses the importance of hard work and that by doing so, success will be the reward.

A student's lack of effort could stem from a lack of experiencing academic success or a lack of academic standards set for them, as previously noted by Benson (2000). However, the findings from this study are inconsistent with the findings from previous studies that found studentathletes felt lower academic expectations by staff (White, 2008) and did not ask for assistance out of fear of being labeled (Stokowski, 2013). In the interviews, student-athletes accurately identified what they perceived their advisor and learning specialist would identify as academic success for them. Participants did not express that there were lower academic expectations for them, despite meeting with a learning specialist. While this study did not deal specifically with student-athletes with learning disabilities, participants did not have an issue asking for help from their learning specialist or advisor. These results show that student-athletes thought they were successful and the academic support staff played a role in that.

\section{Recommendations}

Logan (2015) describes how persons bring a pre-conceived notion of how effective learning takes place. Therefore, advisors and learning specialists must recognize each student's history/background, along with current expectations. When student-athletes first arrive on campus, they should sit down with a learning specialist and an advisor and have a conversation about expectations. Support staff should initiate these conversations and include asking how the student-athlete perceives academic success for them, asking about their academic goals, and explaining what the goals of their meetings with them will be. Finally, student-athletes should be informed of the expectations of each professional. This step is vital in communicating with student-athletes (Pettit, 2013). Summer bridge programs are recommended as a way to have a mini-academic experience and for student-athletes to learn what it will take to succeed academically (Heinel, 2008) and help support staffs initiate these conversations early on before students are busier academically and athletically.

Listening to student-athletes' responses about what academic success means to them, while taking into account any individual academic challenges, enables academic support professionals to help develop a plan for each student to be successful. Having these open and honest conversations early on creates a more proactive approach that could aid in reducing the likelihood that student-athletes fall into eligibility issues. This process also facilitates student-athletes making a smoother transition into the demands of college-level academics and participation in their sport. In addition, it can help student-athletes embrace rather than avoid academic challenges. Conversations between student-athletes and support staff promote self-awareness and consciousness raising, which can lead to a positive change in behavior. Academic exercises can help bridge the gap between knowing what to do and actually putting it into action (Heinel, 2008). Starting with this type of dialogue clarifies the roles and expectations of each person and creates an avenue for open communication, which may help increase satisfaction for everyone. 
The overall view of success among academic advisors, learning specialists, and at-risk student athletes involves attaining academic goals for maintaining eligibility, graduating, achieving personal development goals of growth, maturity, and increased work ethic. Effort was an overarching theme of every participant group in this study, as expressed in the form of expectations and considered to be the essence of academic success. Expectations were identified by the participants as focusing on personal outcomes, such as improved work ethic, maturity, and seeing the hard work pay off with a higher GPA. Success was also described as fulfilling the expectations of the learning specialists, advisors, and coaches. This could include improving their own academic performance and contributing to the overall GPA of the team. Other expectations included becoming a positive role model and a standard setter. Thus, if the student-athlete works with their advisors and learning specialists to identify the areas in which they have poor academic preparedness and learn strategies for overcoming those weaknesses, they can use these strategies to improve their performance in the classroom. Success, then, would be improved academic performance that results in higher regard by coaches, support staff, and teammates as well as a greater sense of self.

\section{Limitations}

This study was designed to provide insight into the academic experiences among studentathletes, learning specialists, and academic advisors. However, there are a number of limitations to this study. To start, the sample size was small for each population and the sample of studentathletes used was not diverse, as all participants were male student-athletes of Caucasian, African American, or mixed ethnicity. This limitation hinders the ability of the findings to be generalized to the total population of student-athletes, since the participant sample lacks diversity in race and sex. Also, all of the participants were members of revenue-generating sports. Perhaps studentathletes participating in sports that are not relied on for financial gain confront different demands than student-athletes participating revenue-generating sports. In addition, the professional participants were not a diverse sample. The majority of professional participants were female and Caucasian. Replications of this study with participants of various ethnicities, NCAA divisions, sports, and members of each sex can provide greater insight into the experiences of student-athletes and support services at the postsecondary level. Additionally, to be chosen as a participant, professionals either volunteered or were chosen by their support services director. Similarly, the advisor and/or learning specialist approached student-athletes who agreed to participate. Therefore, it is not possible to generalize the perceptions of academic success to all studentathletes.

This study is also limited by its reliance on information given in interviews. There was no method used to test whether a subject is telling the truth, since participants were self-reporting. The participants could have been chosen because it was known that they would speak positively about their experience and/or other participant groups. Another limitation to this study is that participants were only used from Division I institutions in the "Power Five" conferences. To provide greater insight into the academic experiences among learning specialists, academic advisors, and student-athletes, researchers should examine institutions outside of the Power Five conferences. 


\section{Future Research}

Future research should investigate the relational dynamic between advisors and learning specialists, as well as coaches and academic support services personnel, in order to develop best practices. There is also a need to look more in depth at the role of learning specialist, since there is little research available and the responsibilities differed greatly among participants. In addition, the influence of gender on job responsibilities and the relational dynamics with student-athletes should be explored, along with how advisors and learning specialists function in roles resembling parenting. Furthermore, studies should examine the experiences of female athletes with support services and should attempt to create a sample matching the racial composition of intercollegiate athletes. Studies should also look to understand if student-athletes feel that they are academically successful based on their own perceptions, like those described in this study. Researchers can also examine similar interview-based data to determine what specific types of effort should be asserted by persons working with at-risk student athletes. Discussion need to be had regarding students' strengths as well as the skills they need to develop for attaining academic goals of not just maintaining eligibility, but also for earning their degree while participating in their sport. Mutually defined goals and behaviors directed towards academic and personal growth result in a true partnership among academic support personnel and student athletes. This is key for studentathletes to have a voice in choosing majors that best complement their interests and future career goals. In so doing, plans can be made in this partnership for class selection, scheduling, tutoring, and whatever else is needed for the student-athlete to progress in their major and complete all requirements for graduation.

\section{Conclusion}

This study looks to change the perception that talking about academic achievement is only "lip service" and that talking about education only relates to eligibility (Beamon, 2008). With the pressure of accountability from multiple sources and the load that advisors already have, they may not have been able to provide all student-athletes with the academic assistance and support needed. It is possible that the addition of learning specialists to academic support staffs could be the link to give these students the time and help they need to actually engage in meaningful learning. The results from this study indicate that both advisors and learning specialists are both vital and different parts of the academic success of student-athletes. Advisors deal more with scheduling and keeping track of eligibility and learning specialists deal more with the relational needs, but both roles are needed when working with student-athletes.

The study fills a gap in the literature regarding the relational and communicative dynamic of learning specialists, academic advisors, and student-athletes. No studies were found that explore this phenomenon. This could be due in part to the fact that the learning specialist profession has recently emerged in college athletics, so there has not been a significant need to conduct research up to this point. As pressure increases for coaches to win, most likely there will continue to be an increase in the number of student-athletes entering college who are special admits, underprepared, and/or have a learning disability. In turn, the number of learning specialists employed in athletic academic support services will also most likely continue to increase. As a result, there is a need to understand the learning specialist role in order to streamline job title responsibilities across institutions, create accurate and effective accountability measures, and develop best practices for 
the profession. This study may be used as a scholarly resource in the academic field and a practical source for academic support services.

It is important for academic support staff to intentionally spend time at the very beginning of a student-athlete's academic journey to explore past educational experiences and current expectations. Exploring these student characteristics can help create a better foundation for a student to not only set academic goals for themselves each semester, but also to think about and set their long-term goals and envision what academic success ultimately looks like for them. The goal is for student-athlete support services to help students become active participants in their educational journey, enabling them to recognize their academic achievements. Once studentathlete support professionals assist students in setting challenging yet obtainable academic goals, they can help students celebrate their success in creative ways outside of just the standard GPA awards. Institutions should be creative in finding ways to celebrate those students who achieve personal goals and milestones that may not fit the typical standards of an academic accolade. One example would be the Baylor University Student Athlete Center for Excellence, which uses "personal best" as a category recognized and celebrated at the end of each semester, along with other more typical academic honors. This is just one example of how athletic departments can celebrate students of all academic levels and be more inclusive in defining academic success. 


\section{References}

Autry, S. L. (2010). Predicting student-athlete success: An analysis of graduation using precollege and college experience variables [Unpublished manuscript]. Florida State University.

Baxter, L. A. (1991). Content analysis. In B. M. Montgomery \& S. Duck (Eds.), Studying interpersonal interaction (pp. 239-254). Guilford Press.

Beamon, K. (2008). "Used Goods": Former African American college student-athletes' perception of exploitation by Division I universities. The Journal of Negro Education, 77(4), 352-364. http://0-www.jstor.org.library.uark.edu/stable/25608704

Benson, K. F. (2000). Constructing academic inadequacy: African American athletes' stories of schooling. Journal of Higher Education, 71, 223-246.

Braxton, J. M. (2003). Student success. In S. R. Komives, Jr. \& D. B. Woodard and Associates (Eds.), Student services: A handbook for the profession. Jossey-Bass.

Brecht, A. A. (2014). A study of the factors that predict academic success and retention of student-athletes (Order No. 3580494). Available from ProQuest Dissertations \& Theses Global. (1539559457). http://0research.proquest.com.library.uark.edu/docview/1539559457?accountid=8361

Butterworth, L. (2015). An exploration of the administrative influence of NCAA regulation: A case study of the changes in the "big football university" athletic academic support unit from 1991-2014. [Unpublished manuscript]. The George Washington University.

Butterworth, J., \& Rich, J. (2013). Examining academic-athletic support and academic success of student athletes. [Honors Theses and Capstones 98]. http://scholars.unh.edu/honors/98

Conley, D. T. (2007). Redefining college readiness. Educational Policy Improvement Center. 
Cooper, J. N., Davis, T. J., \& Dougherty, S. (2017). Not so Black and White: A multi-divisional exploratory analysis of male student-athletes' experiences at National Collegiate Athletic Association (NCAA) institutions. Sociology of Sport Journal, 34(1), 59-78. https://doi.org/10.1123/ssj.2016-0015

Dilley-Knoles, J., Burnett, J. S., \& Peak, K. W. (2010). Making the grade: Academic success in today's athlete. The Sport Journal, 13(1), 1.

Fauria, R. M., \& Zellner, L. J. (2015). College students speak success. Journal of Adult Development, 22(2), 90-99.

Figler, S. (1987). Academic advising for athletes. Journal of Sport and Social Issues, 11(1-2), 74-81.

Floyd, D. L. (1988). Toward mastery leadership: Strategies for student success. Summary report of a colloquium. American College Testing Program.

Fountain, J. J., \& Finley, P. S. (2011). Academic clustering: A longitudinal analysis of a division I football program. Journal of Issues in Intercollegiate Athletics, 4, 24-41.

Getzel, E. E. (2008). Addressing the persistence and retention of students with disabilities in higher education: Incorporating key strategies and supports on campus. Exceptionality, 16(4), 207-219. https://doi.org/10.1080/09362830802412216

Glaser, B., \& Strauss, A. (1967). The discovery of grounded theory: Strategies for qualitative research. Aldine.

Goforth, M. (2016). Embrace the evolution: A historical perspective of the learning specialist position within the athletic academic support field. National Association of Academic Advisors for Athletics. Westlake, $\mathrm{OH}$.

Gragg, D., \& Flowers, R. D. (2014). Factors that positively affect academic performance of African American football student athletes. Journal for the Study of Sports and Athletes in Education, 8(2), 77-98. https://doi.org/10.1179/1935739714Z.00000000020 
Grandy, J., Lough, N., \& Miller, C. (2016). Improving student-athlete academic success: Evaluation of learning support tools utilized by academic advisors for athletics. Journal for the Study of Sports and Athletes in Education, 10(3), 199-217. http://dx.doi.org/10.1080/19357397.2016.1258967

Gurney, G. S., Tan, D., \& Winters, C. (2010). Specially admitted student-athletes: Their academic performance, persistence, and graduation from an NCAA Football Bowl Subdivision university. International Journal of Sport Management, 11, 477-491.

Hanna, G. (2013). The benefit of academic advising for the academic success of college studentathletes (Order No. 1551262). Available from ProQuest Dissertations \& Theses Global. http://0-search.proquest.com.library.uark.edu/docview/1498141316?accountid=8361

Hardin, R., \& Pate, J. R. (2013). Playbook vs. textbook: Examining academic transitioning of NCAA Division I-FBS football student-athletes. Journal for the Study of Sports and Athletes in Education, 7(3), 229-244. https://doi.org/10.1179/1935739713Z.00000000014

Heinel, D. C. (2008). A comparative case study analysis of academically at risk African American male student athletes (Order No. 3325225). Available from ProQuest Dissertations \& Theses Global. http://0search.proquest.com.library.uark.edu/docview/304466556?accountid=8361

Hennink, M., Hutter, I., \& Bailey, A. (2011). Qualitative research methods. Sage.

Hittle, S. (2012). Athletes' tendencies to 'cluster' in certain academic fields problematic, some say. Lawrence-Journal World. https://www2.ljworld.com/news/2012/jun/15/athletestendencies-cluster-certain-academic-field/

Horton, D. (2009). Class and cleats: Community college student athletes and academic success. New Directions for Community Colleges, 147, 15-27. https://doi.org/10.1002/cc.374

Hyatt, R. (2003). Barriers to persistence among African American intercollegiate athletes: A literature review of non-cognitive variables. College Student Journal, 37, 260-275. Gale Document Number: GALE|A103563750

Krippendorff, K. (1980). Content analysis: An introduction to its methodology. Sage. 
LaForge, L., \& Hodge, J. (2011). NCAA academic performance metrics: Implications for institutional policy and practice. The Journal of Higher Education, 8(2), 217-235. https://doi.org/10.1080/00221546.2011.11779092

Lightfoot, D. (2014). Intercollegiate athletics: Student-athlete stress and support. Journal of Higher Education Management, 29, 30-38.

Logan, K. A. (2015). Student-athlete learning: how learning spaces influence athletic and academic success. Electronic Theses and Dissertations. 1038. https://digitalcommons.du.edu/etd/1038

Mason, J. (2002). Qualitative researching. Sage

Meyer, S. K. (2005). NCAA academic reforms: Maintaining the balance between academics and athletics. Phi Kappa Phi Forum, 85(3), 15-18. http://0search.proquest.com.library.uark.edu/docview/235182442? accountid=8361

National Association of Academic Advisors for Athletics. (2007). Learning specialist position and prevalence of special populations. Survey results, Summer 2007. nfoura.org/.../learning-concerns/2007-topics-survey-final-report.pdf

National Collegiate Athletic Association (NCAA) Division I Manual (2012). http://www.ncaapublications.com/productdownloads/D112.pdf

National Collegiate Athletic Association (NCAA)Academic Support Services Evaluation Guide (2009) http://fs.ncaa.org/Docs/AMA/Athletics\%20Cert/N4ANCAA\%20Academic\%20Support\% 20Services\%20Eval\%20Template\%20JP-6-09.pdf

Nichols, M. L., Lough, N. L. \& Corkill, A. J. (2019). Exploring success: Variations in Division I Student-athlete academic and athletic performance. Journal of Issues in Intercollegiate Athletics, 12, 314-342. http://csri-jiia.org

Orcher, L. T. (2016). Conducting research: Social and behavioral science methods. Routledge. 
Owen, W. F. (1984). Interpretive themes in relational communication. Quarterly Journal of Speech, 70, 274-287. https://doi.org/10.1080/00335638409383697

Patton, M. (2002). How to use qualitative methods in evaluation. Sage.

Pettit, N. D. (2013). An investigation into at-risk student-athletes' experiences and academic performance: A case study at San Diego State University (Order No. 3624105) [Doctoral dissertation, San Diego State University]. ProQuest Dissertations \& Theses Global.

Rankin, S., Merson, D., Sorgen C. H., McHale, I., Loya, K., \& Oseguera, L. (2011). Student athlete climate study (SACS) final report. Paper presented at the Association for the Study of Higher Education (ASHE) Annual Conference, Las Vegas, NV. Retrieved from http://rankin-consulting.com/sites/default/files/documents/2011-Student-Athlete-ClimateStudyFinal-Report.pdf

Roueche, J. E., \& Baker, G. A., III. (1987). Access and excellence: The open door college. Community College Press.

Russell, R. K., \& Petrie, T. A. (1992). Academic adjustment of college students: Assessment and counseling. In S. D. Brown \& R. W. Lent (Eds.), Handbook of counseling psychology (pp. 485-511). John Wiley \& Sons.

Saldaña, J. (2016). Ethnotheatre: Research from page to stage. Routledge.

Sedlacek, W. E. (1987). Black students on White campuses: 20 years of research. Journal of College Student Personnel, (November), 484-494.

https://doi.org/10.1.1.895.1821\&rep=rep1\&type=pdf

Steinberg, M. A., Walther, C., Herbst, M., West, J., Zamagias, D., \& Smith, J. (2018). Learning specialists in college athletics: Who are they and what do they do? Journal of Higher Education Athletics \& Innovation, 1, 77-118.

Stokowski, S. E. (2013). I know I can learn: The experiences of NCAA Division I - FBS studentathletes with learning disabilities and/or ADHD in higher education [Doctoral dissertation, University of Tennessee]. http://trace.tennessee.edu/utk_graddiss/1780 
Stokowski, S. E., Dittmore, S. W., \& Stine, G. (2014). A framework for understanding which factors predict positive APR scores at NCAA Division I institutions. Presented at the North American Society for Sport Management conference, May 29-31, Pittsburgh, PA.

Ting, S. R. (2009). Impact of noncognitive factors on first year academic performance and persistence of NCAA division I student athletes. The Journal of Humanistic Counseling, Education and Development, 48(2), 215-228.

Tinto, V. (1997). Classrooms as communities: Exploring the educational character of student persistence. The Journal of Higher Education, 68(6), 599-623.

Tracey, T. J., \& Sedlacek, W. E. (1985). The relationship of non-cognitive variables to academic success: A longitudinal comparison by race. Journal of College Student Personnel, 26(5), 405-410.

Van Etten, S., Pressley, M., McInerney, D. M., \& Liem, A. D. (2008). College seniors' theory of their academic motivation. Journal of Educational Psychology, 100(4), 812828. https://doi.org/10.1037/0022-0663.100.4.812

Weiss, M. P. (2011). Supporting student athletes with disabilities: A case study. Journal of Postsecondary Education and Disability, 24(2), 161-163. http://0search.proquest.com.library.uark.edu/docview/964179928?accountid=8361

White, B. (2008). The academic experiences of and utilization of services by college studentathletes deemed at-risk of not graduating (Order No. 1453718). [Master's thesis, University of Maryland, College Park]. ProQuest Dissertations \& Theses Global.

Wolverton, B. (2016). The hottest hire in athletics? Learning specialists. Chronicle of Higher Education, 62(25), A14. 